https://doi.org/10.46813/2021-131-117

\title{
REFORMING OF ETHANOL IN PLASMA-CATALYTIC SYSTEM WITH DC AND AC ROTATING GLIDING DISCHARGE
}

\author{
O.A. Nedybaliuk, T.A. Tereshchenko ${ }^{1}$, I.I. Fedirchyk ${ }^{1}$, P.V. Tyshchuk ${ }^{1}$, V.P. Demchina ${ }^{2}$ \\ ${ }^{1}$ Taras Shevchenko National University of Kyiv, Kyiv, Ukraine; \\ ${ }^{2}$ Gas Institute of NASU, Kyiv, Ukraine \\ E-mail: oanedybaliuk@gmail.com
}

The article presents the results of the investigation of the reforming of ethanol into synthesis gas using a plasmacatalytic system with either AC or DC wide-aperture rotating gliding discharge. Current and voltage oscillograms of the wide-aperture rotating gliding discharge were measured. The time-dependence of the instantaneous power of the discharge in the air was built. The photographs of the discharge in the airflow and discharge during the ethanol reforming were compared. The optical emission spectra of the plasmas of the torches of AC and DC wide-aperture rotating gliding discharges were studied. The rotational and vibrational temperatures of the plasma torch in the reaction chamber were determined. The results of the gas-chromatography of the synthesis gas produced during the plasm-catalytic reforming of ethanol using either AC or DC rotating gliding discharge are presented.

PACS: 52.50.Dg, 52.80.-s

\section{INTRODUCTION}

The development of technology constantly increases an annual energy demand of the humankind, especially a demand for the electrical energy. The electricity is mainly produced from the underground energy resources (coal, natural gas, uranium, crude oil, etc.). Unfortunately, the use of fossil hydrocarbons, such as coal, natural gas and crude oil, leads to an increase of $\mathrm{CO}_{2}$ concentration in the atmosphere, which contributes significantly to the global warming. In addition, fossil fuels are finite. These pushed the humanity towards the sustainable development technologies [1,2] (a decrease of the production waste, an increase of the energy efficiency, a frugal use of the resources, etc.) and renewable or infinite energy sources (solar, wind, hydro and geothermal energy, biomass, etc.).

The percentage of the electric cars on the transportation market rises each year. However, electric vehicles still have shorter range on one refuel compared to the cars with the internal combustion engine. Meanwhile, the cars based on the fuel cells with the synthesis gas feed can become an alternative solution due to higher energy efficiency and lower ecological impact than the internal combustion engine cars, higher safety than hydrogen cars and higher range than the electric cars. To generate the synthesis gas onboard the car the system need to be small and highly efficient. The plasma-catalytic system with the rotating gliding discharge [3, 4] can fulfill these requirements.

However, such systems require an investigation into which power source should be used for the AC or DC reforming.

\section{EXPERIMENTAL SET-UP}

Fig. 1 shows the scheme of the plasma-catalytic system with rotating gliding discharge for the reforming of ethanol into synthesis gas. The system consisted of the quartz reaction chamber and metal discharge chamber, which were connected by the metal flange.
Reaction chamber height was $100 \mathrm{~mm}$, and its inner diameter was $36 \mathrm{~mm}$. The discharge system had a central T-shaped electrode and a grounded ring electrode with the $20 \mathrm{~mm}$ diameter of the central hole, which also worked as a flange between the discharge and reaction chambers. The distance between the electrodes was $1 \mathrm{~mm}$.

The discharge was powered by either AC or DC power supply. The AC power supply could output up to $30 \mathrm{kV}$ at the set frequency between 30 and $90 \mathrm{kHz}$. The DC power supply consisted of a BP-100 power source and $33 \mathrm{k} \Omega$ ballast resistance, which could provide up to $7 \mathrm{kV}$ of the output voltage.

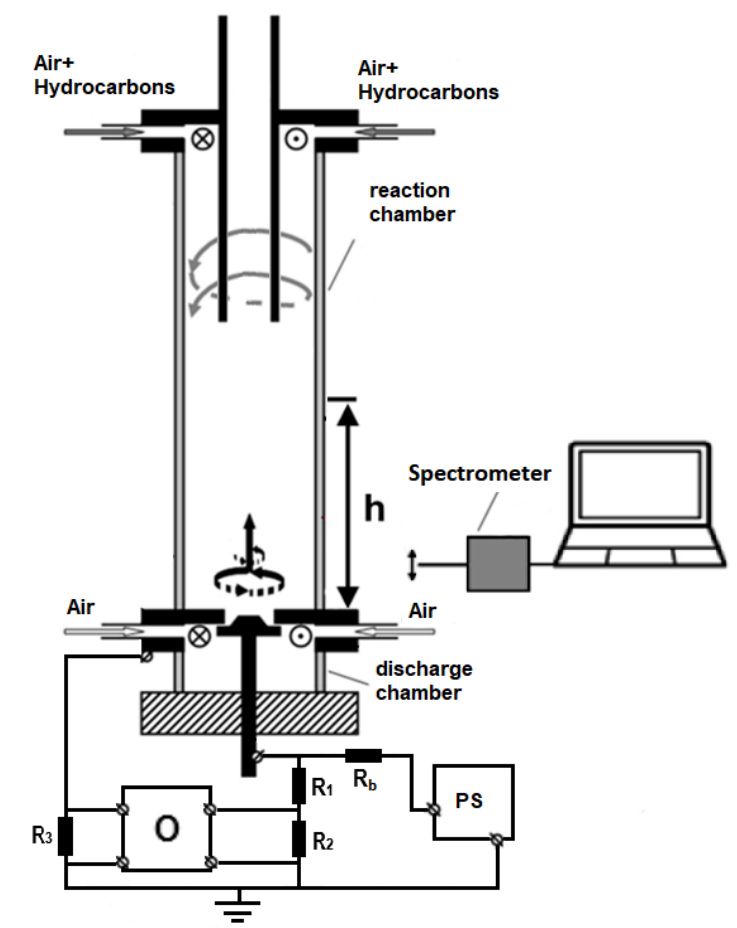

Fig. 1. Scheme of plasma-catalytic system with wideaperture rotating gliding discharge for reforming of ethanol into synthesis gas 
The oscillograms of the discharge voltage and current were measured using an oscilloscope $(\mathrm{O})$ with a voltage divider (resistances $R_{1}$ and $R_{2}, R_{1}: R_{2}=10000: 1$ for $A C$ and $R_{1}: R_{2}=1000: 1$ for $D C$ ) and a measuring resistance $\left(R_{3}=10 \Omega\right)$. The AC and DC discharge operation modes were chosen such as to have approximately the same average discharge current.

During the experiment, ethanol was reformed via partial oxidation with the atmospheric air as an oxygen source. Air was supplied using the Fiac Cosmos air compressor. Total airflow was divided between the discharge chamber and the reaction chamber. The airflows into each chamber were controlled by Dwyer RMA-22 SSV rotameters, the flow of reforming products was measured by Dwyer RMA-23 SSV rotameter [5]. The air that passed through the discharge chamber was used to produce an air plasma, which contained chemically active ions, free radicals, and excited particles. These active species were introduced into the reaction chamber via the torch of the rotating gliding discharge. The air introduced into the reaction chamber was mixed with ethanol, which was supplied into the reaction chamber by a syringe pump at a constant rate. All reactants were introduced into the system tangentially to the walls of the discharge and reaction chambers, which led to the appearance of the vortex flows of the reactants in both chambers. The gas chromatography of the produced synthesis gas was done using Agilent $6890 \mathrm{~N}$ gas chromatograph. The massspectrometry of the obtained synthesis gas was done by MH-7301 mass-spectrometer.

The total introduced airflow during the plasmacatalytic reforming of ethanol was $151 \cdot \mathrm{min}^{-1}$. The flow of air into the discharge chamber was $G_{d}=101 \cdot \mathrm{min}^{-1}$, the flow of air into the reaction chamber was $\mathrm{G}_{\mathrm{r}}=10 \mathrm{l} \cdot \mathrm{min}^{-1}$, and the flow of ethanol into the reaction chamber was $\mathrm{G}_{\text {eth }}=8.5 \mathrm{~g} \cdot \mathrm{min}^{-1}$. The total injected airflow was $51 \cdot \mathrm{min}^{-1}$ higher than required by the stoichiometry of the partial oxidation reaction (1). The stoichiometry for the ethanol reforming (2) was chosen such as to completely oxidize part of the ethanol flow $\left(\mathrm{G}_{\text {eth_h }}=0.69 \mathrm{~g} \cdot \mathrm{min}^{-1}\right) \quad$ (3). This produced energy approximately at a rate of $\mathrm{P}_{\mathrm{h}}=330 \mathrm{~W}$, which was used to heat reactants and keep the reaction chamber at constant temperature (approximately at $200{ }^{\circ} \mathrm{C}$ ).

$$
\begin{gathered}
\mathrm{C}_{2} \mathrm{H}_{5} \mathrm{OH}+0.5 \mathrm{O}_{2}=3 \mathrm{H}_{2}+2 \mathrm{CO} \\
\mathrm{C}_{2} \mathrm{H}_{5} \mathrm{OH}+0.75 \mathrm{O}_{2}=2.75 \mathrm{H}_{2}+1.83 \mathrm{CO}+ \\
+0.25 \mathrm{H}_{2} \mathrm{O}+0.17 \mathrm{CO}_{2} \\
0.08 \mathrm{C}_{2} \mathrm{H}_{5} \mathrm{OH}+0.25 \mathrm{O}_{2}=0.25 \mathrm{H}_{2} \mathrm{O}+0.25 \mathrm{CO}_{2} .
\end{gathered}
$$

As approximately $1 / 12$ of the total ethanol flow would be used to keep the constant temperature of the reaction chamber, the theoretically highest ethanol reforming efficiency $\eta_{\max }$ (4) will be less than $92 \%$ even without considering the energy spent on plasma generation.

$$
\eta_{\max }=\frac{\mathrm{Q}_{\mathrm{C}_{2} \mathrm{H}_{5} \mathrm{OH}-\frac{1}{12}} \mathrm{Q}_{\mathrm{C}_{2} \mathrm{H}_{5} \mathrm{OH}}}{\mathrm{Q}_{\mathrm{C}_{2} \mathrm{H}_{5} \mathrm{OH}}}
$$

Optical emission spectroscopy of plasma radiation, emitted through quartz wall of the reaction chamber, was done using Solar TII S-150-2-3648 USB spectral device with an optical fiber put at a distance $h$ from the top surface of the ring electrode at the bottom of the reaction chamber. The fiber used for light capture was set perpendicularly to the axis of the reaction chamber. Obtained optical emission spectra were used to calculate the rotational and vibrational temperatures of the $\mathrm{OH}$ and $\mathrm{N}_{2}$ molecules inside the reaction chamber. The temperatures were determined by comparing experimental optical emission spectra to the spectra modeled for the specific temperatures using Spec Air 2.2 [6] software. For more information about this method and obtained temperatures please refer to [7-8].

\section{RESULTS AND DISCUSSION}

Fig. 2 presents the photographs of the DC rotating gliding discharge. Fig. 2, a shows the discharge when no ethanol was supplied to the system, while Fig. 2,b shows the discharge during the ethanol reforming. The photograph that was taken during the ethanol reforming (see Fig. 2,b) clearly shows the existence of three zones in the reaction chamber. The first zone is located near the wall of the reaction chamber, where the reactants are heated. The second zone is near the discharge chamber, where the active species are produced in a discharge channel. The third zone is in the middle of the reaction chamber, where reforming takes place. The colors of the second and third zones are distinctly different. Photographs in Fig. 2 point out that the ethanol reforming is initiated by the active species produced in the rotating gliding discharge plasma.

Fig. 3 shows the typical current oscillograms of the AC rotating gliding discharge. The airflow into the discharge chamber was $101 \cdot \mathrm{min}^{-1}$ and the airflow into the reaction chamber was $51 \cdot \mathrm{min}^{-1}$. The output frequency of the AC power supply was set to $(90 \pm 0.5) \mathrm{kHz}$, which corresponds with the obtained current oscillograms (see Fig. 3,a). Over the larger time intervals (100 ms) current oscillograms (see Fig. 3,b) show the pulsations of the current with the period of $10 \mathrm{~ms}$.

Fig. 4 shows the typical current (see Fig. 4,a) and voltage (see Fig. 4,b) oscillograms of the DC rotating gliding discharge as well as its instantaneous power (see Fig. $4, \mathrm{c})$. The airflow into the discharge chamber was $101 \cdot \mathrm{min}^{-1}$ and the airflow into the reaction chamber was $51 \cdot \mathrm{min}^{-1}$. Oscillograms (see Fig. 4) show that the change of current (see Fig. 4,a) correlates with the change of voltage (see Fig. 4,b). The rise of voltage is connected to the change of the length of the discharge channel, which was shown in the previous research on the wide-aperture rotating gliding discharge [7]. The increase of discharge channel length leads to the rise of voltage required for supporting the discharge. At the same time, the current decreases. The power of DC discharge calculated from the values measured by an ammeter and a voltmeter was $100 \mathrm{~W}$, while the average instantaneous power determined from (see Fig. 4,c) was $150 \mathrm{~W}$. 


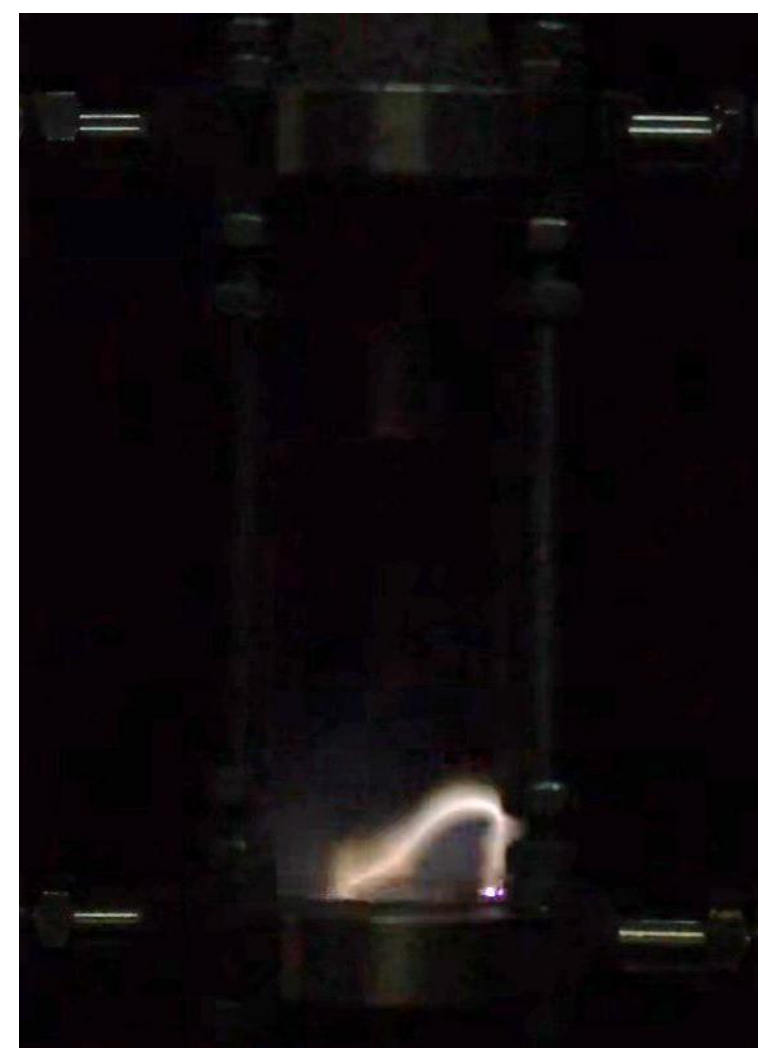

a

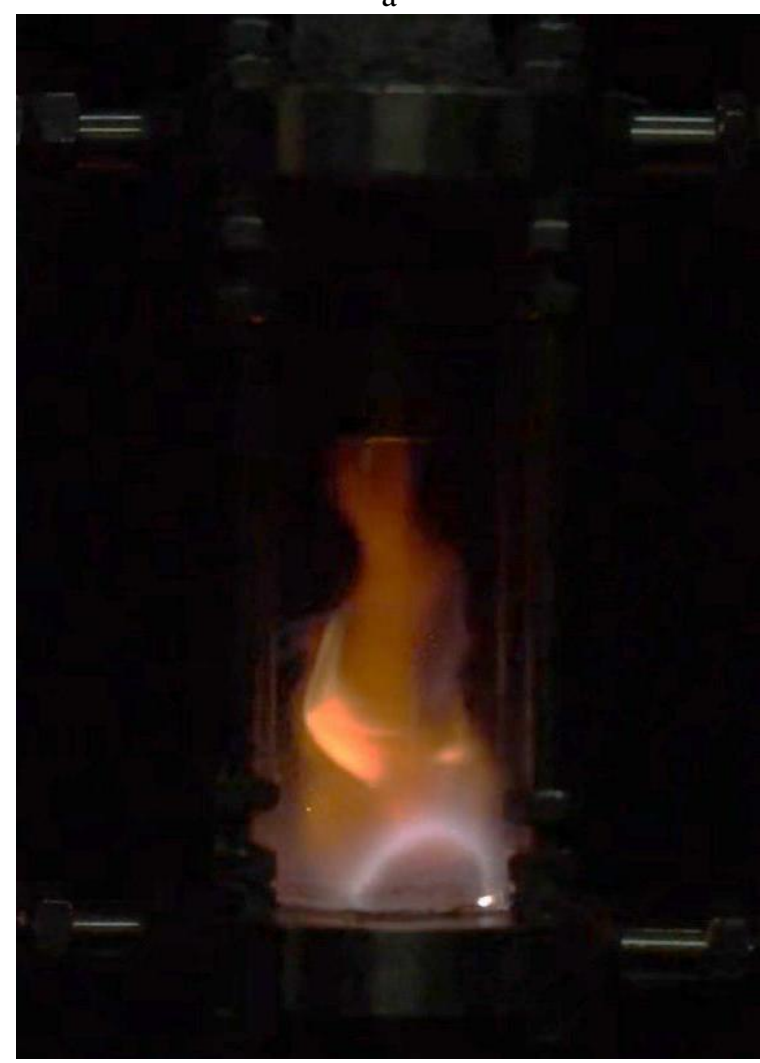

$\mathrm{b}$

Fig. 2. Photograph of rotating gliding discharge at different operation modes (125 $\mu$ s exposition):

$10 \mathrm{l} \cdot \mathrm{min}^{-1}$ airflow into discharge chamber, $5 \mathrm{l} \cdot \mathrm{min}^{-1}$ airflow into reaction chamber, $0 \mathrm{~g} \cdot \mathrm{min}^{-1}$ ethanol flow (a); $10 \mathrm{l} \cdot \mathrm{min}^{-1}$ airflow into discharge chamber,

$5 \mathrm{l} \cdot \mathrm{min}^{-1}$ air flow into reaction chamber, $8.5 \mathrm{~g} \cdot \mathrm{min}^{-1}$ ethanol flow $(\mathrm{b})$
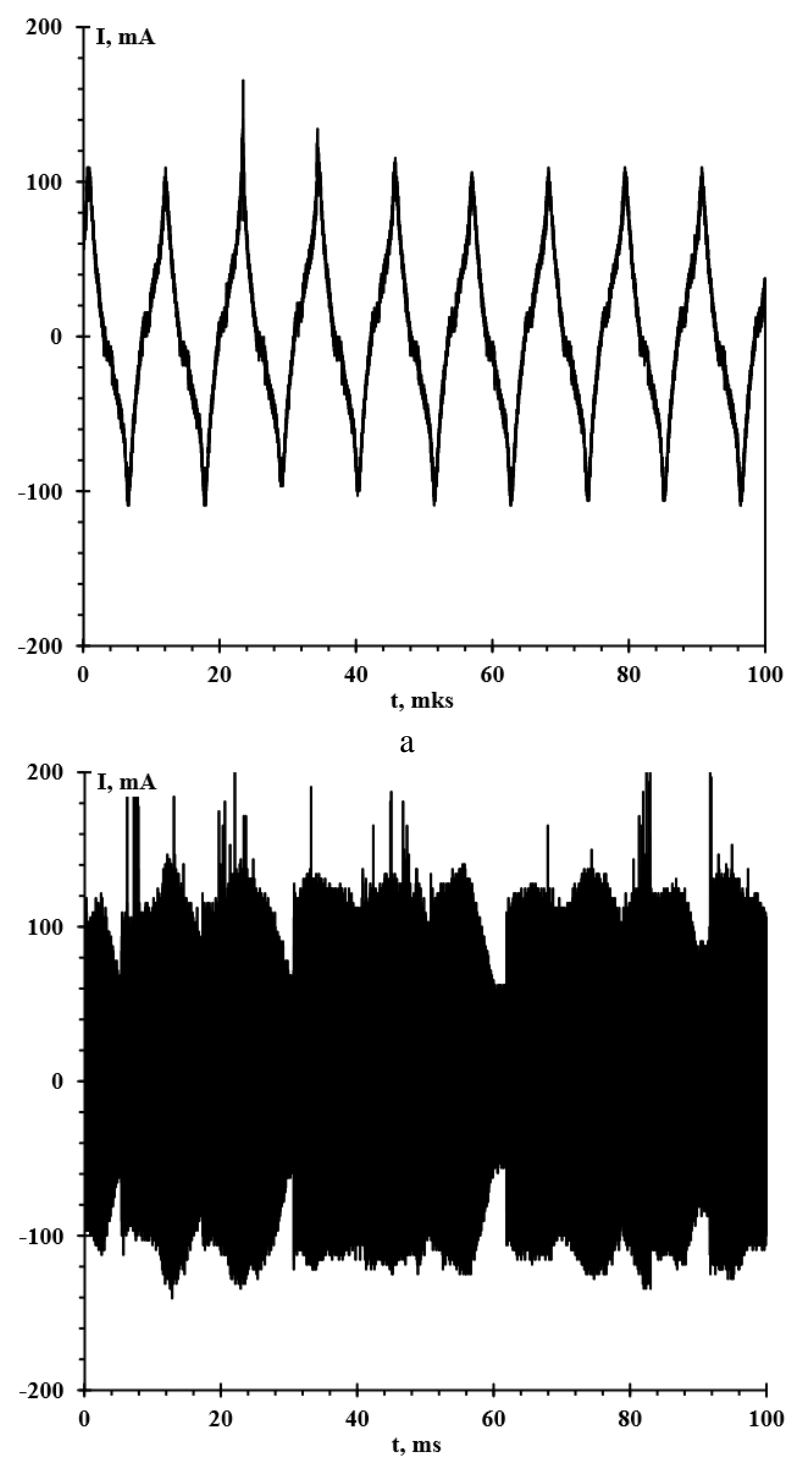

b

Fig. 3. Typical current oscillograms of AC rotating gliding discharge at different time intervals $100 \mu \mathrm{s}(\mathrm{a})$ and $100 \mathrm{~ms}(\mathrm{~b}): 10 \mathrm{l} \cdot \mathrm{min}^{-1}$ airflow into discharge chamber, $5 l \cdot \mathrm{min}^{-1}$ airflow into reaction chamber, $0 \mathrm{~g} \cdot \mathrm{min}^{-1}$ ethanol flow, $90 \mathrm{kHz}$ frequency

Fig. 5 shows the results of the gas chromatography of the syngas samples obtained during the plasmacatalytic reforming of ethanol using $\mathrm{AC}$ and $\mathrm{DC}$ rotating gliding discharges. The flow of air into the discharge chamber was $G_{d}=101 \cdot \mathrm{min}^{-1}$, the flow of air into the reaction chamber was $G_{r}=101 \cdot \mathrm{min}^{-1}$, and the flow of ethanol into the reaction chamber was $G_{\text {eth }}=8.5 \mathrm{~g} \cdot \mathrm{min}^{-1}$. The AC and DC discharge operation modes were chosen such as to have the average discharge current of AC discharge $(60 \mathrm{~mA})$ equal to the discharge current of DC discharge, which was measured by the ammeter. The synthesis gas obtained during the plasma-catalytic reforming of ethanol by the AC rotating gliding discharge has a higher syngas ratio $\left(\mathrm{H}_{2} / \mathrm{CO} \approx 1.5\right)$ than in the case of reforming using $\mathrm{DC}$ discharge $\left(\mathrm{H}_{2} / \mathrm{CO} \approx 1\right)$. The content and flow of hydrogen in the syngas is lower in the case of AC discharge $\left(\mathrm{G}\left(\mathrm{H}_{2}\right)=2.31 \cdot \mathrm{min}^{-1}\right)$ in comparison to the DC discharge $\left(\mathrm{G}\left(\mathrm{H}_{2}\right)=2.81 \cdot \mathrm{min}^{-1}\right)$. 

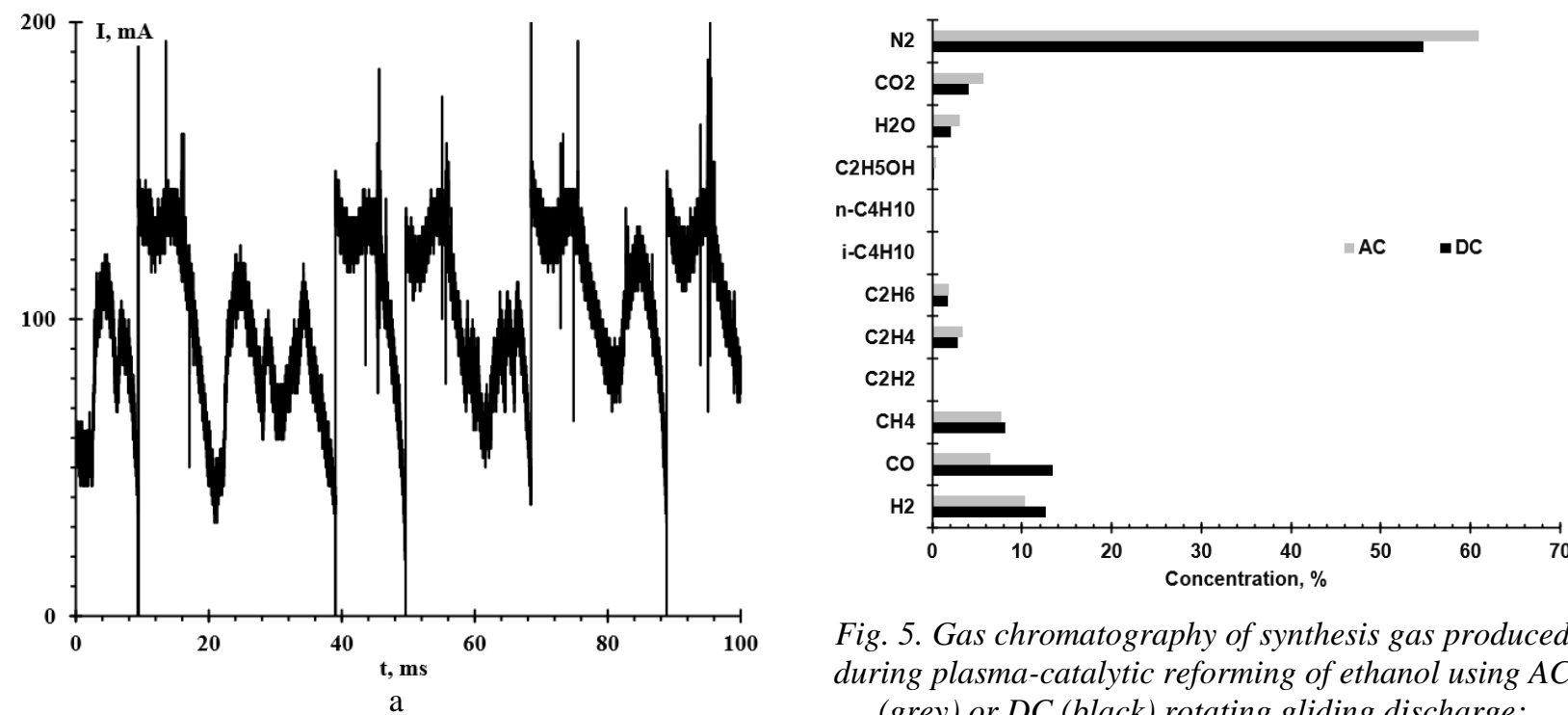

Fig. 5. Gas chromatography of synthesis gas produced during plasma-catalytic reforming of ethanol using AC (grey) or DC (black) rotating gliding discharge:

$10 \mathrm{l} \cdot \mathrm{min}^{-1}$ airflow into discharge chamber, $5 \mathrm{l} \cdot \mathrm{min}^{-1}$ airflow into reaction chamber, $8.5 \mathrm{~g} \cdot \mathrm{min}^{-1}$ ethanol flow

Both mass-spectrometry and gas chromatography showed the same ratios between the concentrations of $\mathrm{H}_{2}$ and $\mathrm{CO}$ and the concentration of nitrogen in reforming products.

Measured optical emission spectra of discharge plasma contain bands of hydroxyl $(\mathrm{OH})$ and nitrogen $\left(\mathrm{N}_{2}\right)$. Nitrogen is present as a major component of the air, while hydroxyl can be produced from the water vapor present in the injected air.

The detailed results of the optical emission spectroscopy of the plasma of the wide-aperture DC rotating gliding discharge operating at different modes can be found in the previous works [7-8].

In the case of the AC discharge, calculated rotational and vibrational temperatures were $\mathrm{T}_{\mathrm{v}}=(5000 \pm 500) \mathrm{K}$ and $\mathrm{T}_{\mathrm{r}}=(1000 \pm 500) \mathrm{K}$, while in the case of the $\mathrm{DC}$ discharge they were $\mathrm{T}_{\mathrm{v}}=(4000 \pm 500) \mathrm{K}$ and $\mathrm{T}_{\mathrm{r}}=(2800 \pm 500) \mathrm{K}$.

\section{CONCLUSIONS}

It was discovered that during the plasma-catalytic reforming of ethanol using rotating gliding discharge the syngas ratio is higher in the case of AC discharge $\left(\mathrm{H}_{2} / \mathrm{CO} \approx 1.5\right)$ than in the case of DC discharge $\left(\mathrm{H}_{2} / \mathrm{CO} \approx 1\right)$. The content and flow of hydrogen in the products of the plasma-catalytic reforming of ethanol using rotating gliding discharge is higher while using the DC discharge $\left(\mathrm{G}\left(\mathrm{H}_{2}\right)=2.81 \cdot \mathrm{min}^{-1}\right)$ in comparison with the AC discharge $\left(\mathrm{G}\left(\mathrm{H}_{2}\right)=2.31 \cdot \mathrm{min}^{-1}\right)$. Despite the lower yield of hydrogen, the system with the AC discharge has a much smaller and lighter power supply, which can become a significant advantage in some applications.

It was discovered that the rotational temperature of plasma species is higher in the $\mathrm{AC}$ discharge $\mathrm{T}_{\mathrm{r}}=(1000 \pm 500) \mathrm{K}$ than in the DC discharge $\mathrm{T}_{\mathrm{r}}=(2800 \pm 500) \mathrm{K}$. 


\section{ACKNOWLEDGEMENTS}

This work was supported in part by the Ministry of Education and Science of Ukraine, National Academy of Sciences of Ukraine, and the Taras Shevchenko National University of Kyiv.

\section{REFERENCES}

1. R. Sheldon. Green Chemistry, Catalysis and Valorization of Waste Biomass // Journal of Molecular Catalysis A: Chemical. 2016, v. 422, p. 3-12.

2. V. Chernyak, O. Nedybaliuk, O. Tsymbaliuk, et al. Plasma chemistry for concept of sustainable development // Problems of Atomic Science and Technology. Series «Plasma Physics». 2017, №1, p. 126-131.

3. O.A. Nedybaliuk, V.Ya. Chernyak, I.I. Fedirchyk, et al. Plasma-catalytic reforming of biofuels and diesel fuel // IEEE Transactions on Plasma Science. 2017, v. 45, №7, p. 1803-1811.

4.D.L. Chernolutsky, V.V. Kolgan, V.Ya. Chernyak, et al. Study of the rotating gliding discharge at atmospheric pressure // Problems of Atomic Science and
Technology. Series «Plasma Physics». 2014, № 6 , p. $175-178$.

5. Dwyer Instruments, Variable Area Flow Corrections // Dwyer Instruments Blog. 2017: http://blog.dwyerinst.com/2017/09/06/variable-area-flowcorrections/\#sthash.syxIW2q1.dpbs.

6. C.O. Laux, T.G. Spence, C.H. Kruger, R.N. Zare. Optical diagnostics of atmospheric pressure air plasma // Plasma Source Sci. Technol. 2003, № 2, p. 125-138. SPECAIR: http://www.specair-radiation.net

7. O.A. Nedybaliuk, I.I. Fedirchyk, V.Y. Chernyak, Plasma-catalytic system with wide-aperture rotating gliding discharge // Problems of Atomic Science and Technology. Series «Plasma Physics». 2018, № 6, p. 214-217.

8. I.I. Fedirchyk, O.A. Nedybaliuk, V.Ya. Chernyak, et al. Plasma-catalytic reforming of rich ethanol-air mixtures // Problems of Atomic Science and Technology. Series «Plasma Physics». 2019, № 1, p. 164-167.

Article received 18.01.2021

\section{РЕФОРМИРОВАНИЕ ЭТАНОЛА В ПЛАЗМЕННО-КАТАЛИТИЧЕСКОЙ СИСТЕМЕ С ВРАЩАТЕЛЬНЫМ СКОЛЬЗЯЩИМ РАЗРЯДОМ ПОСТОЯННОГО И ПЕРЕМЕННОГО ТОКА}

\section{О.А. Недыбалюк, Т.А. Терещенко, И.И. Федирчик, П.В. Тищук, В.П. Демчина}

Представлены результаты исследования реформирования этанола в синтез-газ с использованием плазменно-каталитической системы с широкоапертурным вращающимся скользящим разрядом постоянного и переменного тока. Измерены осциллограммы тока и напряжения горения широко-апертурного вращающегося скользящего разряда. Построена зависимость мгновенной мощности разряда в потоке воздуха от времени. Сопоставлены фотографии горения разряда в потоке воздуха с подачей и без подачи этанола в реакционную камеру. Исследованы эмиссионные спектры плазмы факела широкоапертурного вращающегося скользящего разряда постоянного и переменного тока. Определены температуры (колебательные $\mathrm{T}_{\mathrm{v}}$ и вращательные $\mathrm{T}_{\mathrm{r}}$ ) плазменного факела в реакционной камере. Представлены результаты газовой хроматографии синтез-газа, образованного при реформировании этанола в плазменнокаталитической системе с широкоапертурным вращающимся скользящим разрядом постоянного и переменного тока.

\section{РЕФОРМУВАННЯ ЕТАНОЛУ В ПЛАЗМОВО-КАТАЛІТИЧНІЙ СИСТЕМІ 3 ОБЕРТОВИМ КОВЗНИМ РОЗРЯДОМ ПОСТІЙНОГО ТА ЗМІННОГО СТРУМУ}

\section{О.А. Недибалюк, Т.А. Терещенко, І.І. Федірчик, П.В. Тищук, В.П. Демчина}

Представлено результати дослідження реформування етанолу в синтез-газ з використанням плазмовокаталітичної системи 3 широкоапертурним обертовим ковзним розрядом постійного та змінного струму. Виміряно осцилограми струму i напруги горіння широкоапертурного обертового ковзного розряду. Побудовано залежність миттєвої потужності розряду в потоці повітря від часу. Співставлені фотографії горіння розряду в потоці повітря з подачею та без подачі етанолу в реакційну камеру. Досліджено емісійні спектри плазми факела широкоапертурного обертового ковзного розряду постійного та змінного струму. Визначено температури (коливні $\mathrm{T}_{\mathrm{v}}$ та обертові $\mathrm{T}_{\mathrm{r}}$ ) плазмового факела в реакційній камері. Представлено результати газової хроматографії синтез-газу, утвореного під час реформування етанолу в плазмовокаталітичній системі з широкоапертурним обертовим ковзним розрядом постійного та змінного струму. 